\title{
Synthesis of 2-Substituted Benzothiazole Derivatives and Their In Vitro Anticancer Effects and Antioxidant Activities Against Pancreatic Cancer Cells
}

\author{
NURAY UREMIS ${ }^{1}$, MUHAMMED MEHDI UREMIS ${ }^{1}$, FATMA INANC TOLUN ${ }^{1}$, \\ MUSTAFA CEYLAN ${ }^{2}$, ADEM DOGANER $^{3}$ and AKIF HAKAN KURT ${ }^{4}$ \\ Departments of ${ }^{1}$ Medical Biochemistry, ${ }^{3}$ Biostatistics and Medical Informatics, and \\ ${ }^{4}$ Pharmacology, Faculty of Medicine, Kahramanmaras Sutcu Imam University, Kahramanmaras, Turkey; \\ ${ }^{2}$ Department of Chemistry, Faculty of Science and Letters, Gaziosmanpasa University, Tokat, Turkey
}

\begin{abstract}
Pancreatic cancer is one of the deadliest malignancies characterized by strong resistance to almost all chemotherapeutic agents and radiotherapy. In this study, we aimed to investigate the anticancer effect, enzymatic antioxidant activity [superoxide dismutase (SOD), glutathione peroxidase $(G P x)]$ and total antioxidant capacity (TAC) of synthesized benzothiazole compounds against adenocarcinoma cancer cells (PANC-1). 2-((1S,2S)-2-((E)-4-nitrostyryl)cyclopent-3-en-1$y l)$ benzo[d]thiazole and 2-((IS,2S)-2-((E)-4-fluorostyryl) cyclopent-3-en-1-yl)benzo[d]thiazole containing 2-substituted benzothiazole group were synthesized in two steps. PANC-1 cells were treated with different concentrations of benzothiazole compounds $(5,25,50.75$ and $100 \mu M)$ for $48 h$ and their cytotoxicity effects were determined by the MTT assay. To determine whether these compounds induced apoptosis, PANC1 cells were treated with increasing concentrations of the synthetic products. Our study showed that the synthesized compounds have antiproliferative effects against PANC-1 cells and reduced cell viability. These compounds induced apoptosis of pancreatic cancer cells and at the same time reduced the activity of SOD and GPX and reduced TAC. On the basis of these findings, these synthesized benzothiazole compounds may be considered as a potential therapeutic drug against human PANC-1 cancer cells.
\end{abstract}

Cancer is a major threat to human health and estimated to become the world's deadliest disease. Among all diagnosed

Correspondence to: Akif Hakan Kurt, Ph.D., Department of Pharmacology, School of Medicine, Kahramanmaras Sutcu Imam University 46050 Kahramanmaras, Turkey. Tel: +90 3442802658, Fax: +90 3442802686, e-mail: hkurt@ksu.edu.tr

Key Words: Benzothiazole derivative, antioxidant, cytotoxicity, apoptosis, pancreatic cancer cell. cancers, pancreatic cancer is the fourth leading cause of death in recent decades but this figure is anticipated to move from the fourth to the second place in the U.S. by 2020 (1). Pancreatic cancer is usually diagnosed in late stages, which explains why it is a leading cause of cancer death (2).

Apoptosis is regarded as a crucial element of several processes including normal cell turnover, however, in cancer cells, the process is suppressed and required to be triggered, which is an important mechanism of action of anticancer agents $(3,4)$. Consequently, cancer drugs have been developed that can lead to apoptotic death through a tumorsuppressor protein-dependent pathway (5).

When produced only in moderate amounts or in the absence of sufficient antioxidant defense, reactive oxygen species (ROS) become harmful and lead to initiation of cancer due to imbalance between oxidants and antioxidants (6). The high level of ROS in cancer cells has been utilized to develop ROS-activated anticancer prodrugs that target tumor cells (7). Pancreatic cancer cells are known to generate ROS (8). This leads to oxidative stress, which in turn induces the production of proinflammatory cytokines that induce inflammation $(9,10)$.

Benzothiazole is a class of heterocyclic compounds having sulfur and nitrogen hetero atoms. The analogs of benzothiazole and its derivatives have an important role particularly in medicinal, synthetic, and pharmaceutical chemistry due to their biological and pharmacological activities. Especially in the last few years, some benzothiazoles have found application in bioorganic and medicinal chemistry and in the development of clinical drugs such as pramipexole, lubeluzole, probenazole, ethoxazolamide, zopolrestat and bentaluron (11).

For therapeutic purposes, benzothiazole derivatives have been applied for their anticancer, antitubercular, anti-HIV, antimicrobial, cardiovascular, local anesthetic, anticonvulsant, anti-inflammatory and antidiabetic activities. But better anticancer agents from benzothiazole compounds need to be 


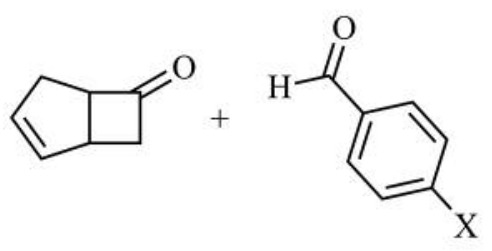

1
2

\section{$\underset{\mathrm{EtOH}, 25^{\circ} \mathrm{C}}{2.5 \mathrm{M} \mathrm{NaOH}}$}

$\mathrm{X}=\mathrm{NO}_{2}, \mathrm{~F}$

Figure 1. Synthesis route of benzothiazole compounds.

developed with minimum side-effects to prevent and treat cancer (11). In this context, we describe the synthesis, spectroscopic data, antioxidant and antiproliferative activity against PANC-1 pancreatic cancer cells of 2-substituted benzothiazoles 2-((1S,2S)-2-((E)-4-nitrostyryl)cyclopent-3-en1-yl)benzo[d]thiazole and 2-((1S,2S)-2-((E)-4-fluorostyryl) cyclopent-3-en-1-yl)benzo[d]thiazole. We examine dosedependent antioxidant properties of these synthesized benzothiazoles against PANC-1 cell line in vitro, taking into consideration the important role of ROS in cancer formation.

\section{Materials and Methods}

Materials. All the reagents and chemicals were supplied by SigmaAldrich (Darmstadt, Germany) and Merck (Darmstadt, Germany) and were used without purification. Melting points of synthesized compounds were measured with Electrothermal 9100 apparatus (Bibby Sci. Ltd, Stone, Staffordshire, UK). Reactions were controlled by using pre-coated silica gel aluminum backed thin layer chromatography (TLC) Kiselgel plates (Merck) 60 F254 Merck in hexane: ethyl acetate (95:5). Column chromatography was performed for purification with Silica Gel 60. 230-400 meshes (hexane:ethyl acetate). Infrared spectroscopy (IR) spectra were recorded by a PerkinElmer FT-IR Spectrometer 400 (Waltham, MA, USA) (resolution: $0.5-4 \mathrm{~cm}^{-1}$ ). ${ }^{1} \mathrm{H}$ and ${ }^{13} \mathrm{C}$ nuclear magnetic resonance (NMR) spectra were recorded using a Brucker Avance III instrument (Billerica, MA, USA) using deuterated chloroform $\left(\mathrm{CDCl}_{3}\right)$ as solvent. Elemental analyses $(\mathrm{C}, \mathrm{H}, \mathrm{N}, \mathrm{S})$ were performed using a LECO CHNS 932 elemental analyzer (St. Joseph, MI, USA). UV-Visible absorption measurements were performed using a Shimadzu TCC-240A spectrophotometer (Kyoto, Japan) with $1 \mathrm{~cm}$ length quartz cells. Enzyme-linked immunosorbent assay (ELISA) measurements were carried out in a Thermo Scientific Multiskan FC (Vantaa, Finland) microplate reader using 96-well microtiter-plates.

Synthesis of chalcone derivatives. Chalcone derivatives were synthesized based on Claisen-Schmidt condensation as previously reported (12). $\mathrm{NaOH}$ was added to a powerfully stirred solution of cis-bicyclo[3.2.0]hept-2-en-6-one ( 1 in Figure 1$)$ and aldehyde derivatives ( 2 in Figure 1). The resulting solution was stirred for 4 hours at room temperature. Chloroform was added to the mixture and the organic phase was washed, dried with sodium sulfate and filtered. Solid compound was recrystallized in ethyl acetate/nhexane (1:9). The obtained compound $\mathbf{3} \mathbf{a}$ and $\mathbf{3 b}$ were used in the next step (Figure 1).

(E)-7-(4-Nitrobenzylidene)bicyclo[3.2.0]hept-2-en-6-one (3a): Yield: $87 \%$; mp: $166-170{ }^{\circ} \mathrm{C} ;{ }^{1} \mathrm{H}-\mathrm{NMR}\left(400 \mathrm{MHz}, \mathrm{CDCl}_{3}\right)$ : $\delta=8.28$ $(\mathrm{d}, \mathrm{J}=8.8 \mathrm{~Hz}, 2 \mathrm{H}), 7.74(\mathrm{~d}, \mathrm{~J}=8.8 \mathrm{~Hz}, 2 \mathrm{H}), 6.89$ (s, 1H), 6.00-5.94 $(\mathrm{m}, 2 \mathrm{H}), 4.48-4.46(\mathrm{~m}, 1 \mathrm{H}), 3.92-3.88(\mathrm{~m}, 1 \mathrm{H}) ; 2.78(\mathrm{bd}, \mathrm{J}=17.6 \mathrm{~Hz}$, $1 \mathrm{H}), 2.58(\mathrm{dd}, \mathrm{J}=17.6,10.4 \mathrm{~Hz}, 1 \mathrm{H}) .{ }^{13} \mathrm{C}-\mathrm{NMR}\left(100 \mathrm{MHz}, \mathrm{CDCl}_{3}\right)$ : $\delta=203.3,153.1,147.9,140.6,134.4,130.2$ (2 C), 127.7, $124.2(2$ C), 121.2, 61.3, 49.9, 35.1.

(E)-7-(4-Florobenzylidene)bicyclo[3.2.0]hept-2-en-6-one (3b): Yield: $82 \%$; mp: $80-84^{\circ} \mathrm{C}$; ${ }^{1} \mathrm{H}-\mathrm{NMR}\left(400 \mathrm{MHz}, \mathrm{CDCl}_{3}\right): \delta=7.59$ (dd, J=8.8, 5.6 Hz, 2H), $7.12(\mathrm{t}, \mathrm{J}=8.8 \mathrm{~Hz}, 2 \mathrm{H}), 6.84(\mathrm{~d}, \mathrm{~J}=2.0 \mathrm{~Hz}$, $1 \mathrm{H}), 6.03-6.00(\mathrm{~m}, 1 \mathrm{H}), 5.90-5.88(\mathrm{~m}, 1 \mathrm{H}), 4.38-4.37(\mathrm{~m}, 1 \mathrm{H}), 3.95-$ $3.92(\mathrm{~m}, 1 \mathrm{H}), 2.83-2.77(\mathrm{dm}, \mathrm{J}=15.2 \mathrm{~Hz}, 1 \mathrm{H}), 2.64-2.56$ (ddd, $\mathrm{J}=15.2,8.8,2.9 \mathrm{~Hz}, 1 \mathrm{H}) .{ }^{13} \mathrm{C}-\mathrm{NMR}\left(100 \mathrm{MHz}, \mathrm{CDCl}_{3}\right): \delta=203.7$, $164.8,162.3,148.9,133.6,131.8,131.7,130.5,130.4,128.5,123.0$. $116.4,116.1,60.749 .4,34.7$.

Synthesis of benzothiazole derivatives. Benzothiazole compounds were synthesized from chalcone compounds $\mathbf{3 a}$ and $\mathbf{3 b}$ (1.0 equivalent) then reacted with 2 -amino-thiophenol (1.0 equivalent) in ethanol $(50 \mathrm{ml})$ in the presence of $p$-toluene sulfonic acid. The mixture was then refluxed for 10 hours, monitoring by TLC and then cooled. Chloroform was added to the reaction mixture and the organic phase was washed, dried with sodium sulfate and filtered. The final products $(\mathbf{4 a}$ and $\mathbf{4 b})$ were purified by chromatography with hexane and an increasing amount of ethyl acetate (0-15\%) yielding a waxy solid.

2-((1S,2S)-2-((E)-4-nitrostyryl)cyclopent-3-en-1-yl)benzo[d] thiazole (4a): Yield: $82 \%$; ${ }^{1} \mathrm{H}-\mathrm{NMR}\left(400 \mathrm{MHz}, \mathrm{CDCl}_{3}\right)$ : $\delta=8,18(\mathrm{~d}$, $J=8.1 \mathrm{~Hz}, 2 \mathrm{H}), 8.01(\mathrm{~d}, J=8.1 \mathrm{~Hz}, 1 \mathrm{H}), 7.88(\mathrm{~d}, J=8.0 \mathrm{~Hz}, 1 \mathrm{H})$, 7.61-7.44 (m, 3H), $7.39(\mathrm{t}, J=7.6 \mathrm{~Hz}, 1 \mathrm{H}), 6.64-6.47(\mathrm{~m}, 2 \mathrm{H}), 6.06-$ $5.95(\mathrm{~m}, 1 \mathrm{H}), 5.85-5.76(\mathrm{~m}, 1 \mathrm{H}), 4.01(\mathrm{ddt}, J=6.9,4.5,2.2 \mathrm{~Hz}, 1 \mathrm{H})$, $3.80(\mathrm{dt}, J=8.8,7.4 \mathrm{~Hz}, 1 \mathrm{H}), 3.12(\mathrm{ddt}, J=13.3,6.7,2.2 \mathrm{~Hz}, 1 \mathrm{H})$, 3.02-2.89 (m, $1 \mathrm{H}) .{ }^{13} \mathrm{C}-\mathrm{NMR}\left(100 \mathrm{MHz}, \mathrm{CDCl}_{3}\right): \delta=174.31$, 153.01, 146.73, 143.60. 136.59, 134.87, 131.62, 130.91, 128.87, 
$126.78,126.07,124.95,123.98,122.74,121.58,77.37,77.06,76.74$ $56.61,50.08,40.22$. IR $\left(\mathrm{KBr}, \mathrm{cm}^{-1}\right): 3058,2848,1593,1503,1436$, 1337, 1107, 968, 856, 756, 727, 437. Elemental Anal. Calc. for $\mathrm{C}_{20} \mathrm{H}_{16} \mathrm{~N}_{2} \mathrm{O}_{2} \mathrm{~S}$ : C, 68.94; H, 4.63; N, 8.04; S, 9.20. Found: C, 67.37; $\mathrm{H}, 4.35 ; \mathrm{N}, 7.56 ; \mathrm{S}, 8.79 \%$.

2-((1S,2S)-2-((E)-4-florostyryl)cyclopent-3-en-1-yl)benzo[d] thiazole (4b): Yield: $80 \%$; ${ }^{1} \mathrm{H}$ NMR $\left(400 \mathrm{MHz}, \mathrm{CDCl}_{3}\right)$ : $\delta=8.02(\mathrm{~d}$, $J=8.2 \mathrm{~Hz}, 1 \mathrm{H}), 7.87(\mathrm{~d}, J=7.8 \mathrm{~Hz}, 1 \mathrm{H}), 7.48$ (ddd, $J=8.3,7.2,1.3$ $\mathrm{Hz}, 2 \mathrm{H}), 7.43-7.31(\mathrm{~m}, 4 \mathrm{H}), 7.06-6.97(\mathrm{~m}, 2 \mathrm{H}), 6.46(\mathrm{~d}, J=15.8 \mathrm{~Hz}$, $1 \mathrm{H}), 6.22(\mathrm{dd}, J=15.8,8.0 \mathrm{~Hz}, 1 \mathrm{H}), 5.98-5.92(\mathrm{~m}, 1 \mathrm{H}), 5.82-5.76$ $(\mathrm{m}, 1 \mathrm{H}), 3.99-3.87(\mathrm{~m}, 1 \mathrm{H}), 3.77(\mathrm{dt}, J=8.8,7.3 \mathrm{~Hz}, 1 \mathrm{H}), 3.16-3.03$ $(\mathrm{m}, 1 \mathrm{H}), 3.00-2.89(\mathrm{~m}, 1 \mathrm{H}) .{ }^{13} \mathrm{C} \mathrm{NMR}\left(101 \mathrm{MHz}, \mathrm{CDCl}_{3}\right)$ : $\delta=174.82,153.03,134.91,132.43,131.17,131.15,130.21,129.59$, $127.79,127.71,125.96,124.80$. 122.68, 121.54, 115.50. 115.28, 77.36, 77.04, 76.72, 56.66, 50.31, 40.07. IR $\left(\mathrm{KBr}, \mathrm{cm}^{-1}\right): 3064$, 2925, 1599, 1506, 1434, 1326, 1221, 1157, 981, 822, 720. 707, 671, 532, 432. Elemental Anal. Calc. for $\mathrm{C}_{20} \mathrm{H}_{16} \mathrm{FNS}$ : C, 74.74; H, 5.02; N, 4.36; S, 9.98. Found: C, 73.13; H, 5.66; N, 4.29; S, 9.72\%.

Cell culture. PANC-1 cells were obtained from the American Tissue Culture Collection (Manassas, VA, USA). Cells were cultured as described previously (13). In brief, cells were cultured in high glucose Dulbecco's modified Eagles medium (DMEM) (Gibco Life Technologies, Carlsbad, CA, USA) supplemented with $100 \mathrm{U} / \mathrm{ml}$ penicillin (Sigma-Aldrich, St. Louis, MO, USA) and 10\% fetal bovine serum (FBS; Gibco Life Technologies) at $37^{\circ} \mathrm{C}$ in a humidified atmosphere of $5 \% \mathrm{CO}_{2}$. Media were replaced every 2-3 days. For 3 days prior to the experiment, PANC-1 cells were cultured with phenol red-free high glucose DMEM. The negative control condition for all assays was performed by culturing the cells for 48 $\mathrm{h}$ in the absence of synthesized benzothiazole compounds $(0 \mu \mathrm{M})$.

Cytotoxic studies-MTT assay. Cell viability was assessed by MTT assay (Sigma). Cells were seeded into 96-well transparent flat bottom plates (Greiner Bio-One, Frickenhausen, Germany) at a density of $1 \times 10^{5}$ cells/well for $24 \mathrm{~h}$. After $24 \mathrm{~h}$ of incubation at $37^{\circ} \mathrm{C}$, the medium was removed and the cells were treated with synthesized benzothiazole compounds $(0.5,25,50.75$ and $100 \mu \mathrm{M})$. The plate was incubated at $37^{\circ} \mathrm{C}$ for $48 \mathrm{~h}$ after which the medium was removed. Then, $200 \mu \mathrm{l}$ of MTT reagent $(1 \mathrm{mg} / \mathrm{ml})$ in serum-free medium was added to each well. After 4hours, the medium was removed and 200 $\mu$ limethyl sulfoxide (DMSO) was added to each well. The metabolized MTT product dissolved in DMSO was quantified by reading the absorbance at a wavelength of $570 \mathrm{~nm}$ on a micro plate reader (Thermo Scientific Multiskan). We used gemcitabine, a chemotherapeutic agent used against pancreatic carcinomal (14), as positive control and untreated cells $(0 \mu \mathrm{M})$ as negative control for cell toxicity. The $50 \%$ inhibitory concentration $\left(\mathrm{IC}_{50}\right)$ values were calculated and the $\mathrm{IC}_{50}$ curves were plotted using GraphPad Prism 3 (La Jolla, CA, USA) based on a sigmoidal dose-response equation.

Apoptosis assay. PANC-1 human pancreatic cells were seeded in flat-bottom plates and after $24 \mathrm{~h}$ of incubation at $37^{\circ} \mathrm{C}$, the medium was removed and the cells were treated with synthesized benzothiazole compounds $(0.5,25,50.75$ and $100 \mu \mathrm{M})$. The plate was incubated at $37^{\circ} \mathrm{C}$ for $48 \mathrm{~h}$. Cells were lysed, and measurement of DNA defragmentation was estimated using the cell death detection ELISAPLUS kit (Roche Applied Science, Germany) following the manufacturer's protocol. Absorbance was determined at $405 \mathrm{~nm}$. The enrichment factor was calculated as the ratio of the absorbance of the sample cells to the absorbance of control cells as described elsewhere (15). An enrichment factor of 1 or more represents background or spontaneous apoptosis.

Determination of superoxide dismutase (SOD) and glutathione peroxidase (GPX) activities. PANC-1 human pancreatic cancer cells were treated with different concentrations $(0.5,25,50.75$ and $100 \mu \mathrm{M})$ of synthesized benzothiazoles and incubated for $48 \mathrm{~h}$. After the incubation period, the medium was removed and cell pellets were then lysed in phosphate buffer (PBS, pH 7.0), followed by sonication for $2 \mathrm{~min}$ on ice. To obtain supernatant, the mixture was centrifuged at $14,000 \times g$ for $10 \mathrm{~min}$ and assayed for enzyme activities and protein concentration. Protein levels were calculated by the Lowry method (16). SOD activity was determined with Fridovich method (17). The GPx assay was based on the oxidation of NADPH to $\mathrm{NADP}^{+}$, which leads to a decrease in absorbance at $340 \mathrm{~nm}$. The rate of this decline is directly proportional to the GPx activity in the sample (18)

Determination of total antioxidant capacity (TAC). TAC was measured by colored 2,2-azinobis-(3-ethylbenzothiazoline-6sulfonic acid) radical cation $\left(\mathrm{ABTS}^{+}\right) . \mathrm{ABTS}^{+}$is decolorized by antioxidants depending on their concentration and antioxidant capacities. This color change was determined as a change in absorbance at $660 \mathrm{~nm}$. The assay was calibrated with Trolox and results were expressed as mmol Trolox equivalent/l (19).

Statistical analysis. Kruskal-Wallis test was used to determine if differences between treatment groups for each parameter were statistically significant. A level of $p<0.05$ was considered as statistically significant. All values in text, figures and tables are expressed as the mean \pm standard deviation (SD). The data were analyzed using GraphPad Prism 3.0.

\section{Results}

Chemistry. The target compounds were obtained in two steps, as described above (Figure 1). Compounds $\mathbf{4 a}$ and $\mathbf{4 b}$ were synthesized from reaction between 2-amino-thiophenol with chalcones $\mathbf{3 a}$ and $\mathbf{3 b}$ in ethanol at reflux (10 h) in good yield (Table I). All spectral data of compounds $\mathbf{4 a}$ and $\mathbf{4 b}$ $\left({ }^{1} \mathrm{H}\right.$ NMR, ${ }^{13} \mathrm{C}$ NMR, IR, elemental analysis) corresponded with the proposed structures.

Cytotoxicity against PANC-1 cancer cell line. The cytotoxic effect of benzothiazole derivatives (4a and 4b) on PANC-1 human pancreatic cancer cells was determined by MTT assay after treatment with 5 to $100 \mu \mathrm{M}$ of the compounds for $48 \mathrm{~h}$. Treatment with increasing concentrations of synthesized benzothiazole compounds $(0.5,25,50.75$ and $100 \mu \mathrm{M})$ led to a concentration-dependent inhibition of cell growth (Figure 2). While gemcitabine had a half-maximal inhibitory concentration $\left(\mathrm{IC}_{50}\right)$ of $52 \pm 0.72 \mu \mathrm{M}$ for PANC-1 cells, the synthesized benzothiazole compounds had $\mathrm{IC}_{50}$ values of $27 \pm 0.24 \mu \mathrm{M}(\mathbf{4 a})$ and $35 \pm 0.51 \mu \mathrm{M}(\mathbf{4 b})$. The inhibitory effect of the synthesized benzothiazole compounds on pancreatic cancer cells was greater than that of gemcitabine. 
Table I. Structure and physical characteristics of synthesized compounds.

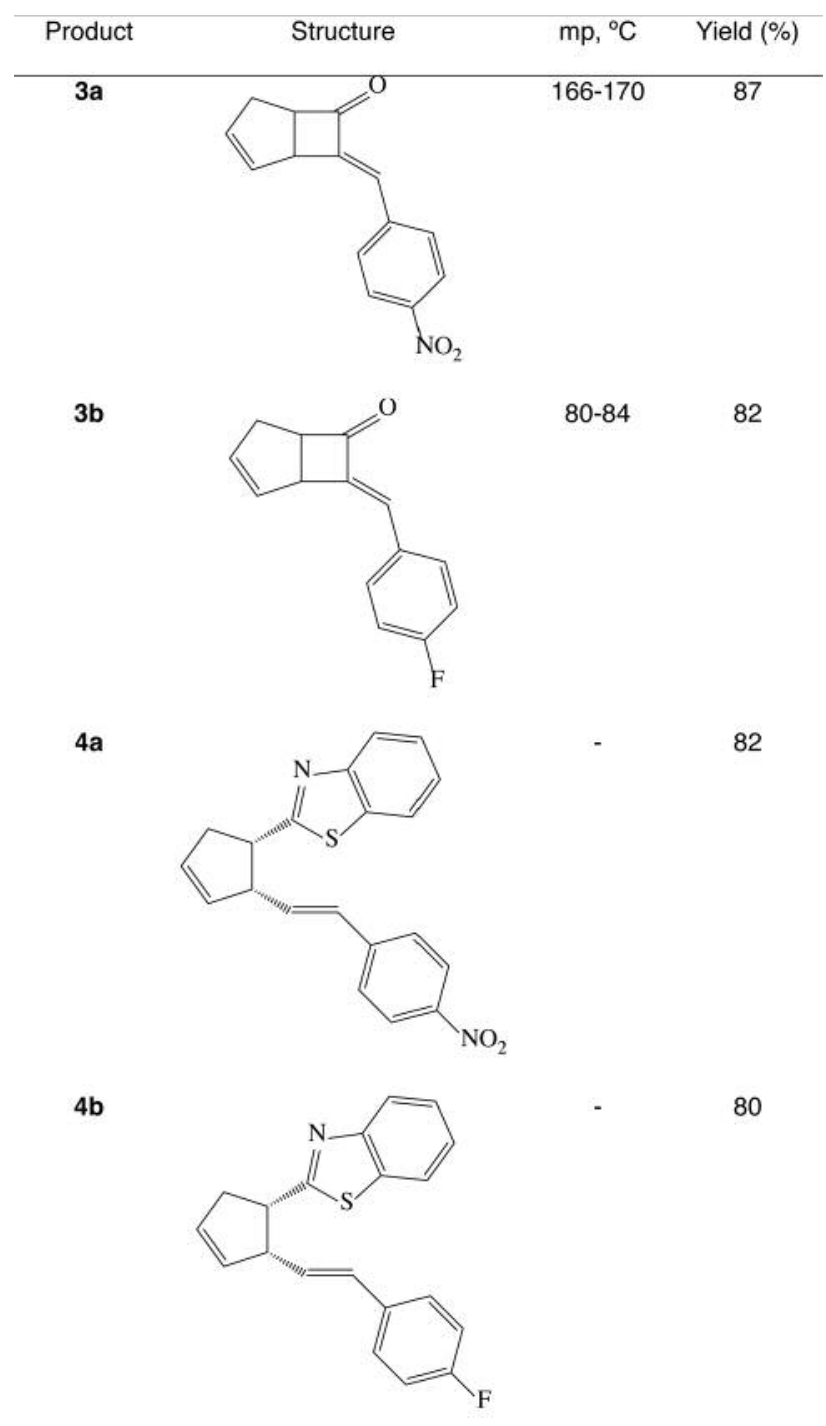

Cell apoptosis assay. Although cytotoxicity and cell viability is often determined by MTT assay, this assay does not differentiate between cell death from apoptosis and necrosis. We performed an apoptosis assay to determine if the cytolysis of PANC-1 cells after treatment with synthesized benzothiazole compounds is apoptotic. This assay provides a quantitative determination of cytoplasmic histoneassociated DNA fragments stemming from DNA degradation that result specifically in apoptotic cells. As shown in Figure 3 , the rate of apoptotic cells increased in a concentrationdependent manner when treated with synthesized benzothiazole compounds. Treatment of cells with $100 \mu \mathrm{M}$ or $75 \mu \mathrm{M}$ compound $4 \mathrm{a}$ for $48 \mathrm{~h}$ resulted in increased number of apoptotic cells ranging from 1.35- to 1.51 -fold over that the control $(0 \mu \mathrm{M})$. Also, in comparison with the controls $(0 \mu \mathrm{M})$, the rate of apoptotic cells in PANC-1 culture was 1.35 fold higher after incubation with compound $\mathbf{4 b}$ at $100 \mu \mathrm{M}$. These results demonstrate that treatment with synthesized benzothiazole compounds induced apoptosis of PANC-1 cells in vitro.

Effect on SOD and GPx activities, and TAC. In general, all concentrations $(5,25,50.75,100 \mu \mathrm{M})$ of $\mathbf{4 a}$ and $\mathbf{4 b}$ effectively reduced SOD and GPx activity in treated pancreatic adenocarcinoma cells compared to untreated control cells. For SOD activity, the decrease was significant at 50.75 and $100 \mu \mathrm{M} 4 \mathbf{a}$ when compared to the control (Figure 4A). Among the five doses, 75 and $100 \mu \mathrm{M}$ caused greater decreases in GPx level (Figure 4B).

Compound $4 \mathbf{b}$ effectively reduced the activities of SOD and GPx in PANC-1 pancreatic cancer cells compared with the control group. The decrease in SOD activity was greater at 75 and $100 \mu \mathrm{M}$ doses when compared to the control group (Figure 5A). With respect to GPx levels, benzothiazole compounds significantly strongly reduced GPx at 75 and 100 $\mu \mathrm{M}$ concentrations (Figure 5B) compared to the control group.

TAC was also determined in culture supernatants. Figure 4C and 5C show that there were statistically significant differences in TAC values between untreated PANC-1 cells and those that were treated with synthesized benzothiazole compound. Among the five doses, 25, 50 and $100 \mu \mathrm{M}$ doses of compound 4a caused greater decrease in TAC (Figure 4C). On the other hand, $\mathbf{4 b}$ led to a greater decrease at 100 $\mu \mathrm{M}$ concentration (Figure $5 \mathrm{C}$ ) compared to the other treatment groups.

\section{Discussion}

Benzothiazole is a privileged heterocyclic scaffold possessing diverse pharmaceutical applications. The potent antitumor activities displayed by various 2-arylbenzothiazole derivatives have reinforced their importance in the development of newer and effective antitumor agents. Moreover, broad-spectrum antimicrobial activity demonstrated by benzothiazole derivatives make them agents of choice for the development of antimicrobial lead drugs. Furthermore, promising anticancer, anti-inflammatory, neuroprotective, antidiabetic, analgesic and many other activities demonstrated by molecules containing a benzothiazole nucleus make it a much sought after scaffold for the development of corresponding therapies. In recent years, a large number of patents have been filed discussing various pharmacological properties of benzothiazoles, signifying the potential of this scaffold for the development of new chemical entities in the treatment of diseases/disorders (20).

Tumorigenesis is ascribed to uncontrolled proliferation as well as induced ROS and reduced p53-dependent apoptosis (21). Medicinal and pharmaceutical chemistry have been a 
A

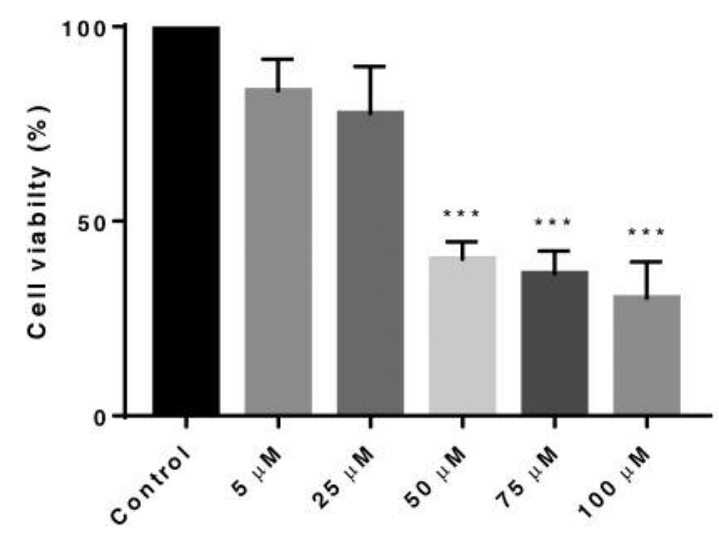

B

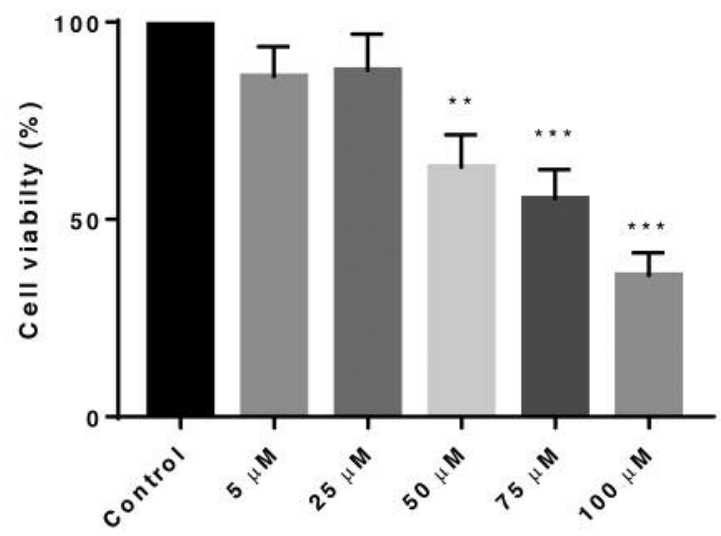

Figure 2. Effects of compound $\mathbf{4 a}(A)$ and $\mathbf{4 b}(B)$ on the viability of PANC-1 cells as determined by MTT assay. PANC-1 cells were treated with different concentrations of compounds $\mathbf{4 a}$ and $\mathbf{4 b}$ for $48 \mathrm{~h}$. The values are the mean $\pm S D$ presented as a percentage that of the untreated control. Significantly different at $* * p<0.01$ and $* * * p<0.001$ versus the control group.

A

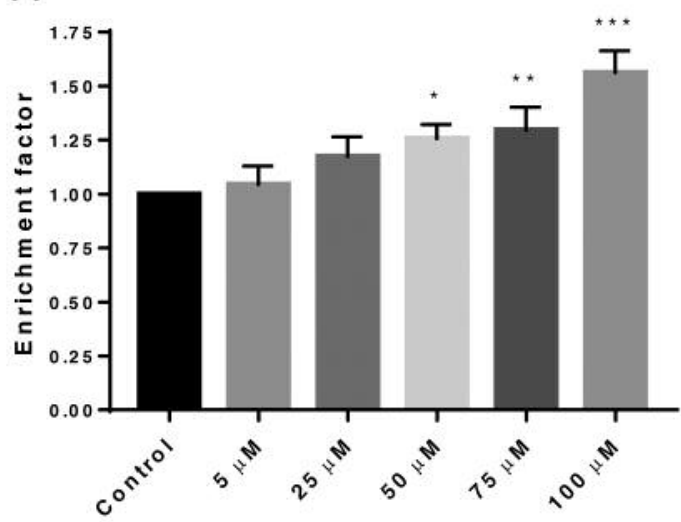

B

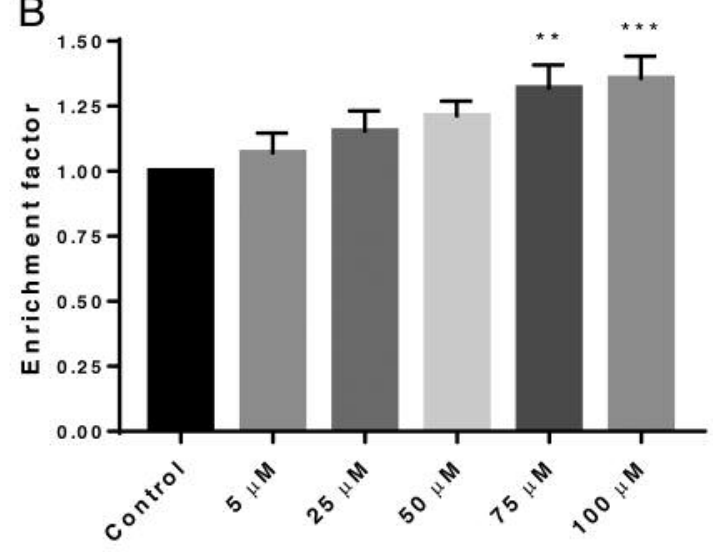

Figure 3. Induction of apoptosis by compounds $\mathbf{4 a}(A)$ and $\mathbf{4 b}(B)$ in PANC-1 cells. PANC-1 cells were treated with different concentrations of synthesized benzothiazole compounds for $48 \mathrm{~h}$. After $48 \mathrm{~h}$ of treatment, cell death detection ELISA was used to determine the apoptotic cell death. The values are expressed as means $\pm S D$ relative to the untreated control. Significantly different at $* p<0.05$, **p<0.01 and ***p<0.001 versus the control group.

substantial source from which great number of apoptosisinducing agents have been obtained (11). The induction of apoptosis in tumor cells is the most extensive mechanism of anticancer drug action in many cancer therapies (22). Recent studies revealed that benzothiazole derivatives possess cytotoxic and antitumor effects on several tumor cell lines in vitro (20.23) and in vivo (24). Our previous study showed that benzothiazole compounds dose-dependently inhibit the proliferation of C6 (rat brain tumor) and HeLa (human uterine cancer) cell lines (25). These results are supported by our present finding that compounds 2-((1S,2S)-2-((E)-4- nitrostyryl)cyclopent-3-en-1-yl)benzo[d]thiazole (4a) and 2$((1 \mathrm{~S}, 2 \mathrm{~S})-2-((E)-4$-florostyryl)cyclopent-3-en-1-yl)benzo[d] thiazole (4b) displayed an inhibitory effect on the proliferation of pancreatic cancer cell lines in a dose-dependent manner.

Gemcitabine is generally used in therapy of pancreatic, bladder, breast, ovarian and non-small cell lung (26-30) cancer. Both compounds $\mathbf{4 a}$ and $\mathbf{4 b}$ demonstrated potent cytotoxicity towards PANC-1 cells, with $\mathrm{IC}_{50}$ of $27 \pm 0.24 \mu \mathrm{M}$ and $35 \pm 0.51 \mu \mathrm{M}$, respectively. Gemcitabine, which was used as positive control, had an $\mathrm{IC}_{50}$ of $52 \pm 0.72 \mu \mathrm{M}$. We demonstrated that benzothiazole compounds had much 
A

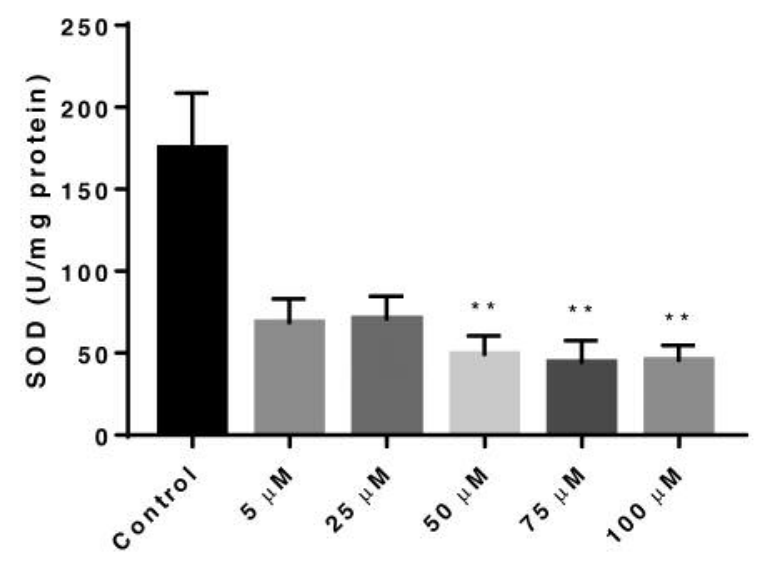

B

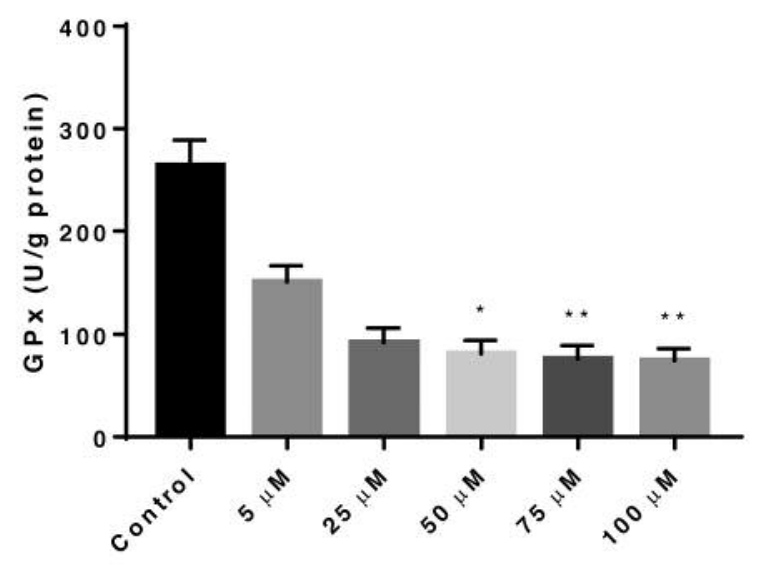

C

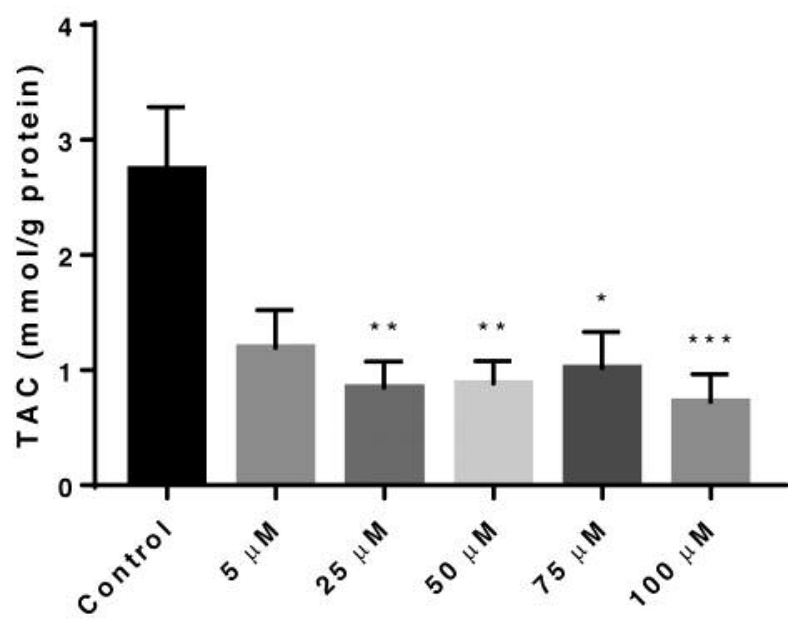

Figure 4. Effect of compound $4 \boldsymbol{a}$ on superoxide dismutase (SOD) activity $(A)$; glutathione peroxidase (GPx) activity $(B)$ and total antioxidant capacity (TAC) (C) in PANC-1 cells. The values are expressed as means $\pm S D$. Significantly different at $* p<0.05, * * p<0.01$ and $*^{* *} p<0.001$ versus the (untreated) control group.
A

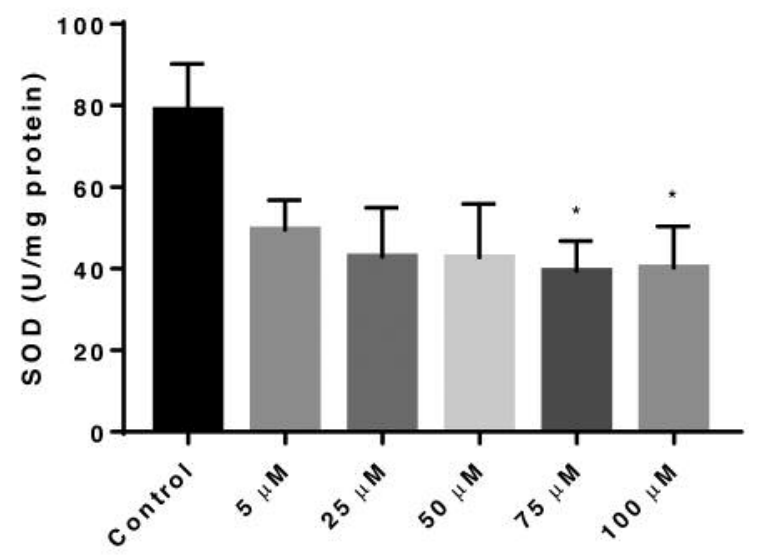

B

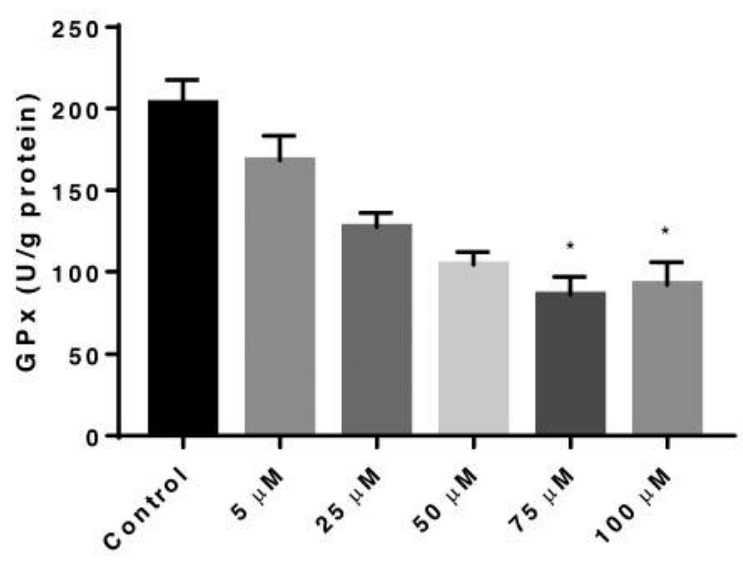

C

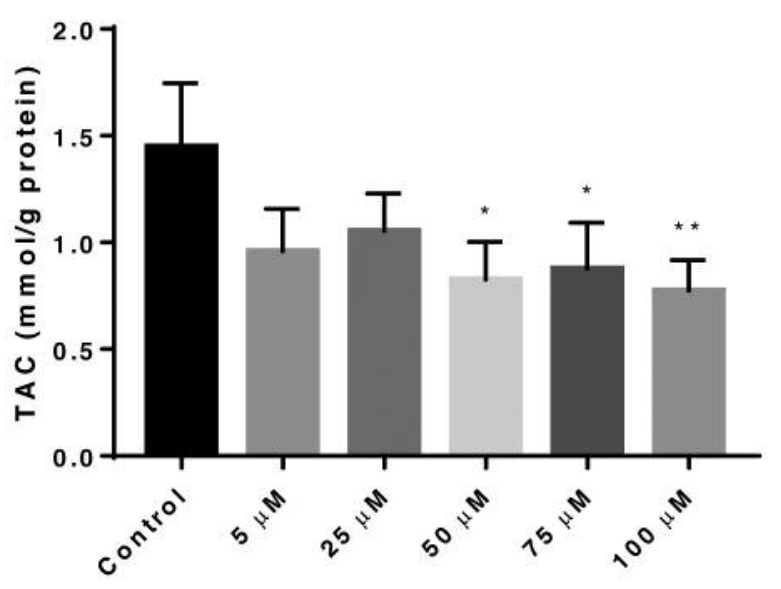

Figure 5. Effect of compound $\mathbf{4 b}$ on superoxide dismutase (SOD) activity $(A)$, glutathione peroxidase (GPx) activity (B), and total antioxidant capacity (TAC) (C) in PANC-1 cells. The values are expressed as means $\pm S D$. Significantly different at $* p<0.05$ and $* * p<0.01$ versus the (untreated) control group. 
higher cytotoxicity to the PANC-1 pancreatic cancer cell line in comparison with gemcitabine. In addition, the present study suggests that the inhibition of cell viability involves apoptosis observed in using cell death detection ELISA. Experimental results showed a concentration-dependent increase in apoptosis. Therefore, benzothiazole derivative compounds might act as potential antitumor compounds that are worth studying, particularly in relation to their effect on mechanisms of apoptosis and apoptosis signaling pathway.

Proteins are prone to alteration and damage by oxidative stress and these actions lead to different pathological conditions. Oxidative stress may be an early event in the activation of the apoptotic machinery (31). ROS at high concentrations are cytotoxic to pancreatic cancer cells. Therefore, ROS-mediated DNA damage abrogates malignant conversion of cells and tumorigenesis. Therapeutic attempts enhance pro-oxidant formation could preferably destroy pancreatic tumor cells through cellular oxidative stress. The ability of benzothiazole derivative compounds to increase cellular levels of ROS may be connected with their capacity to selectively target tumor cells $(32,33)$.

Available studies suggest that in many cancer cell lines, SOD activity was significantly higher in than healthy control groups regardless of tumor localization. According to our data, SOD activity was higher in untreated PANC-1 cells when compared to results obtained from PANC-1 cells treated with synthesized benzothiazole compounds. Rodrigues et al. evaluated anticancer effect of a new benzothiazole compound by investigating its antioxidant effects on breast cancer cells. Their results demonstrated that cancer cells were able to relatively recover from the cytotoxic effects of this compound. This compound caused significant inhibition of GPx and SOD activity (34). The results of the current study showed that glutathionedependent enzyme (GPx) activities were significantly higher in untreated PANC-1 cells than in other groups. Likhar et al. designed and synthesized a series of 2-aryl substituted benzothiazole with various substituted benzoic acids. The compounds showed significant radical-scavenging capacity because of the presence of electron-donating substituents (35). These findings indicate that benzothiazole derivatives act as a defence mechanism by preventing the formation of excess free radicals. In our study, TAC were assessed in all groups an indicator of oxidative stress. Examination of TAC may be more functional instead of individual determination of oxidants and antioxidants (19). We found a significant difference between untreated PANC-1 cells and those treated with benzothiazole compounds in terms of mean TAC.

Inclusion of antioxidant drugs in the complex therapy of oncological patients may be important for control of oxidantantioxidant imbalance. Thus, in this study we investigated applicability of benzothiazole compounds for correction of metabolic impairments through oxidative stress in PANC-1 cells. There is increased production of ROS by tumor cells and also induction of antioxidant systems (36). Synthesized compounds have been a primary source from which various apoptosis-inducing agents are obtained. As reported by various scientific studies, synthesized compounds may be effective in cancer inhibition or therapy $(23,37,38)$. These studies demonstrated that bioactive compounds cause apoptosis of tumor cells $(20,39)$. In this regard, benzothiazole derivatives are well-recognized compounds used for the treatment and prevention of various tumors (40).

In conclusion, benzothiazole derivative compounds exhibited cytotoxic and apoptosis effects by regulating cell viability, antioxidant system in PANC-1 cancer cells. With further research, benzothiazole analogs may prove to be potent in assisting the treatment of tumor and improvement of anticancer drugs. The findings of this study demonstrated that the compound may be promising as an anticancer agent. However, further and larger in vitro and in vivo studies are needed to confirm these data and to establish fully the effect of synthesized benzothiazole compounds.

\section{Conflicts of Interest}

The Authors state no conflicts of interest exist in regard to this study.

\section{Acknowledgements}

This study was supported by Kahramanmaras Sutcu Imam University Research Foundation (Project no: 2015/1-56M). Benzothiazole derivatives in the current work have been firstly synthesized in a project supported by TUBITAK-The Scientific and Technological Research Council of Turkey (Project no: 111T111).

\section{References}

1 Matrisian LM, Aizenberg R and Rosenzweig A: The alarming rise of pancreatic cancer deaths in the united states: Why we need to stem the tide today. Pancreatic Cancer Action Network, 2012, available at https://www.pancan.org/wp-content/uploads/ 2013/01/incidence_report_2012.pdf (last accessed 19-05-2017).

2 Pai M and Spalding D: Pancreatic cancer. Medicine 43(6): 329333, 2015.

3 Faraj FL, Zahedifard M, Paydar M, Looi CY, Abdul Majid N, Ali HM, Ahmad N, Gwaram NS and Abdulla MA: Synthesis, characterization, and anticancer activity of new quinazoline derivatives against MCF-7 cells. Scientific World J 2014: 212096, 2014.

4 Hunter AM, LaCasse EC and Korneluk RG: The inhibitors of apoptosis (IAPs) as cancer targets. Apoptosis 12(9): 1543-1568, 2007.

5 Elmore S: Apoptosis: A review of programmed cell death. Toxicol Pathol 35(4): 495-516, 2007.

6 Kim MJ, Kim DH, Na HK and Surh YJ: Tnf-alpha induces expression of urokinase-type plasminogen activator and betacatenin activation through generation of ROS in human breast epithelial cells. Biochem Pharmacol 80(12): 2092-2100, 2010. 
7 Peng X and Gandhi V: ROS-activated anticancer prodrugs: A new strategy for tumor-specific damage. Ther Deliv 3(7): 823833,2012

8 Zhang L, Li J, Zong L, Chen X, Chen K, Jiang Z, Nan L, Li X, Li W, Shan T, Ma Q and Ma Z: Reactive oxygen species and targeted therapy for pancreatic cancer. Oxid Med Cell Longev 2016: 1616781, 2016.

9 Arifa RD, Paula TP, Madeira MF, Lima RL, Garcia ZM, Avila TV, Pinho V, Barcelos LS, Pinheiro MV, Ladeira LO, Krambrock $\mathrm{K}$, Teixeira MM and Souza DG: The reduction of oxidative stress by nanocomposite fullerol decreases mucositis severity and reverts leukopenia induced by irinotecan. Pharmacol Res 107: 102-110, 2016.

10 Esposito K, Nappo F, Marfella R, Giugliano G, Giugliano F, Ciotola M, Quagliaro L, Ceriello A and Giugliano D: Inflammatory cytokine concentrations are acutely increased by hyperglycemia in humans: Role of oxidative stress. Circulation 106(16): 2067-2072, 2002.

11 Seth S: A comprehensive review on recent advances in synthesis and pharmacotherapeutic potential of benzothiazoles. Antiinflamm Antiallergy Agents Med Chem 14(2): 98-112, 2015.

12 Ceylan M and Findik E: Synthesis and characterization of new chalcone derivatives from cis-bicyclo[3.2.0]hept-2-en-6-one. Synth Comm 39(6): 1046-1054, 2009.

13 Kurt AH, Celik A and Kelleci BM: Oxidative/antioxidative enzyme-mediated antiproliferative and proapoptotic effects of the gper1 agonist g-1 on lung cancer cells. Oncol Lett 10(5): 3177-3182, 2015.

14 Nakamura K, Yamaguchi T, Sudo K, Ishihara T and Saisho H: Combination chemotherapy with gemcitabine and S-1 for advanced pancreatic cancer. Gan To Kagaku Ryoho 33(Suppl 1): 219-223, 2006.

15 Kulms D, Poppelmann B, Yarosh D, Luger TA, Krutmann J and Schwarz T: Nuclear and cell membrane effects contribute independently to the induction of apoptosis in human cells exposed to UVB radiation. Proc Natl Acad Sci USA 96(14): 7974-7979, 1999.

16 Lowry OH, Rosebrough NJ, Farr AL and Randall RJ: Protein measurement with the folin phenol reagent. J Biol Chem 193(1): 265-275, 1951.

17 Fridovich I: Quantitative aspects of the production of superoxide anion radical by milk xanthine oxidase. J Biol Chem 245(16): 4053-4057, 1970.

18 Levander OA, Deloach DP, Morris VC and Moser PB: Platelet glutathione-peroxidase activity as an index of selenium status in rats. J Nutr 113(1): 55-63, 1983.

19 Erel O: A novel automated direct measurement method for total antioxidant capacity using a new generation, more stable ABTS radical cation. Clin Biochem 37(4): 277-285, 2004.

$20 \mathrm{Kamal}$ A, Syed MA and Mohammed SM: Therapeutic potential of benzothiazoles: A patent review (2010-2014). Expert Opin Ther Pat 25(3): 335-349, 2015.

21 Zhang X, Wei H, Liu Z, Yuan Q, Wei A, Shi D, Yang X and Ruan J: A novel protoapigenone analog RY10-4 induces breast cancer MCF-7 cell death through autophagy via the AKT/MTOR pathway. Toxicol Appl Pharmacol 270(2): 122128,2013

22 Fischer U and Schulze-Osthoff K: Apoptosis-based therapies and drug targets. Cell Death Differ 12(Suppl 1): 942-961, 2005.
23 Lindgren EB, de Brito MA, Vasconcelos TR, de Moraes MO, Montenegro RC, Yoneda JD and Leal KZ: Synthesis and anticancer activity of (E)-2-benzothiazole hydrazones. Eur $\mathrm{J}$ Med Chem 86: 12-16, 2014.

24 Kamal A, Reddy KS, Khan MN, Shetti RV, Ramaiah MJ, Pushpavalli SN, Srinivas C, Pal-Bhadra M, Chourasia M, Sastry GN, Juvekar A, Zingde S and Barkume M: Synthesis, DNAbinding ability and anticancer activity of benzothiazole/ benzoxazole-pyrrolo[2,1-c][1,4]benzodiazepine conjugates. Bioorg Med Chem 18(13): 4747-4761, 2010.

25 Akdogan N: Synthesis and investigation in vitro anticancer (antiproliferative) activities of a new class of (2-(2-styrylcyclopentyl)benzo[d]thiazole) derivatives. Gaziosmanpasa University, Tokat, 2013.

26 Gatzemeier U, Groth G, Butts C, Van Zandwijk N, Shepherd F, Ardizzoni A, Barton C, Ghahramani P and Hirsh V: Randomized phase II trial of gemcitabine-cisplatin with or without trastuzumab in HER2-positive non-small-cell lung cancer. Ann Oncol 15(1): 19-27, 2004.

27 Lorusso V, Crucitta E, Silvestris N, Catino A, Caporusso L, Mazzei A, Guida M, Latorre A, Sambiasi D, D'Amico C, Schittulli F, Calabrese P and De Lena M: Phase I/II study of gemcitabine plus mitoxantrone as salvage chemotherapy in metastatic breast cancer. Br J Cancer 88(4): 491-495, 2003.

28 Mattiucci GC, Ippolito E, D'Agostino GR, Alfieri S, Antinori A, Crucitti A, Balducci M, Deodato F, Luzi S, Macchia G, Smaniotto D, Morganti AG and Valentini V: Long-term analysis of gemcitabine-based chemoradiation after surgical resection for pancreatic adenocarcinoma. Ann Surg Oncol 20(2): 423-429, 2013.

29 Von der Maase H, Hansen SW, Roberts JT, Dogliotti L, Oliver T, Moore MJ, Bodrogi I, Albers P, Knuth A, Lippert CM, Kerbrat P, Sanchez Rovira P, Wersall P, Cleall SP, Roychowdhury DF, Tomlin I, Visseren-Grul CM and Conte PF: Gemcitabine and cisplatin versus methotrexate, vinblastine, doxorubicin, and cisplatin in advanced or metastatic bladder cancer: Results of a large, randomized, multinational, multicenter, phase III study. J Clin Oncol 18(17): 3068-3077, 2000.

30 Khan MF, Gottesman S, Boyella $\mathrm{R}$ and Juneman E: Gemcitabine-induced cardiomyopathy: A case report and review of the literature. J Med Case Rep 8: 220, 2014.

31 Kok SH, Gambari R, Chui CH, Yuen MC, Lin E, Wong RS, Lau FY, Cheng GY, Lam WS, Chan SH, Lam KH, Cheng CH, Lai PB, Yu MW, Cheung F, Tang JC and Chan AS: Synthesis and anticancer activity of benzothiazole containing phthalimide on human carcinoma cell lines. Bioorg Med Chem 16(7): 36263631, 2008.

32 Toyokuni S, Okamoto K, Yodoi J and Hiai H: Persistent oxidative stress in cancer. FEBS Lett 358(1): 1-3, 1995.

33 Szatrowski TP and Nathan CF: Production of large amounts of hydrogen peroxide by human tumor cells. Cancer Res 51(3): 794-798, 1991.

34 Rodrigues JR, Charris J, Camacho J, Barazarte A, Gamboa N and Antunes F: Cytotoxic effects of $N^{\prime}$-formyl-2-(5nitrothiophen-2-yl) benzothiazole-6-carbohydrazide in human breast tumor cells by induction of oxidative stress. Anticancer Res 32(7): 2721-2726, 2012.

35 Likhar R, Perumal P, Kolhe N, Bhaskar VH and Daroi P: Synthesis and antioxidant activity of novel 2-aryl substituted benzothiazole derivatives. Int J Curr Pharmaceut Res 7(4): 34$37,2015$. 
36 Liou GY and Storz P: Reactive oxygen species in cancer. Free Radic Res 44(5): 479-496, 2010.

37 Singh M, Modi A, Narayan G and Singh SK: Benzothiazole derivatives bearing amide moiety: Potential cytotoxic and apoptosis-inducing agents against cervical cancer. Anticancer Drugs 27(6): 519-532, 2016.

38 Mohamed LW, Taher AT, Rady GS, Ali MM and Mahmoud AE: Synthesis and cytotoxic activity of certain benzothiazole derivatives against human MCF-7 cancer cell line. Chem Biol Drug Des 89(4): 566-576, 2017.

39 Ashraf M, Shaik TB, Malik MS, Syed R, Mallipeddi PL, Vardhan MV and Kamal A: Design and synthesis of cis- restricted benzimidazole and benzothiazole mimics of combretastatin A-4 as antimitotic agents with apoptosis inducing ability. Bioorg Med Chem Lett 26(18): 4527-4535, 2016.

40 Gill RK, Rawal RK and Bariwal J: Recent advances in the chemistry and biology of benzothiazoles. Arch Pharm 348(3): 155-178, 2015.
Received May 5, 2017

Revised May 17, 2017

Accepted May 19, 2017 